\title{
Cloning of upstream region and cellulose synthase operon genes involved in bacterial cellulose biosynthesis by Gluconacetobacter hansenii ATCC23769
}

\author{
Carolina Véspoli de Melo ${ }^{1 *}$, Tatiana Souza-Moreira ${ }^{1}$, Sandro Roberto Valentini ${ }^{1}$, Cleslei Fernando Zanelli ${ }^{1}$, \\ Sidney José Lima Ribeiro
}

From 5th Congress of the Brazilian Biotechnology Society (SBBIOTEC)

Florianópolis, Brazil. 10-14 November 2013

\section{Background}

Cellulose is a homopolysaccharide composed of extracellular D-glucose monomers connected by glycosidic linkages in $\beta-1,4$ conformation which can be synthesized by a variety of living organisms, possessing numerous applications in food, pharmaceutical, medical area, etc.[1][2]. In 1990, cellulose synthase operon encoding four proteins required for bacterial cellulose (BC) biosynthesis by Gluconacetobacter hansenii was isolated. It was demonstrated that these genes $b c s A, b c s B, b c s C$ and $b c s D$ were, together, required for maximum production of celulose [3]. Later, researches identified other relevant regions for bacterial cellulose biosynthesis that occur upstream (cmcax and $c c p A x$ genes) and downstream of the operon (bglx gene) [4]. In this study, we aimed to clone the most important genes related to the BC synthesis. With the purpose of cloning those genes, the genomic DNA of the mentioned microorganism was extracted and proceeded with the amplification of cmcax, ссрAx and cellulose synthase operon genes. Later, the genes were ligated to a cloning vector, transformed in Escherichia coli and the identity of the clones was confirmed by sequencing and comparing with the GenBank using Blastn tool. The cloning achievement of the operon and upstream genes from $G$. hansenii and their overexpression will enable studies on $B C$ synthesis improvement.

\section{Methods}

Extraction of bacterial genomic DNA was carried out using cell lysis under heating in the presence of sodium

${ }^{1}$ School of Pharmaceutical Sciences, UNESP, Araraquara, SP, Brazil Full list of author information is available at the end of the article dodecyl sulfate (SDS) and proteinase K, followed by purification with a phenol:chloroform:isoamylic alcohol solution (PCI) and subsequent dialysis in TE buffer $\mathrm{pH}$ 8.0. The cloning of the genes related to the production of bacterial cellulose was carried out with amplification reactions (PCR) using specifically designed primers in the presence of Pfx Plantinum (Invitrogen) or Phusion (New England Biolabs) polymerases. The cloned genes were ligated to pTZ57R/T vector, transformed into ultracompetent Escherichia coli (DH10B) and sequencing was carried out using Big Dye ${ }^{\mathbb{B}}$ Terminator v3.1 Cycle Sequencing Kit and the Genetic Analyzer 3130 (Applied Biosystems). Identity was confirmed with Blastn tool (Basic Local Alignment Search Tool).

\section{Results}

PCR reactions using G. hansenii genomic material and specific primers yield the fragments with the corresponding size of the upstream region $(2.1 \mathrm{~kb})$ and of cellulose synthase operon $(9.0 \mathrm{~kb})$. Finally, the sequencing of the cloned fragments allowed the confirmation of the identity of the genes cmcax and ccpAx and the genes of the BC operon from $G$. hansenii.

\section{Conclusions}

The obtained clones showed high identity with the genes located in the upstream region of the cellulose synthase operon and with the genes in the $\mathrm{BC}$ operon. The next step will allow the overexpression of these genes in G. hansenii ATCC23769 in order to check the cellulose production by the genetically modified microorganism in comparison with the wild microorganism. 


\section{Acknowledgements}

FAPESP, CNPq and PADC - UNESP.

\section{Authors' details}

${ }^{1}$ School of Pharmaceutical Sciences, UNESP, Araraquara, SP, Brazil. ${ }^{2}$ Chemistry Institute, UNESP, Araraquara, SP, Brazil.

Published: 1 October 2014

\section{References}

1. Blackwell J: The macromolecular organization of cellulose and chitin. In Cellulose and Other Natural Polymer Systems. New York: Plenum Press;Brown Jr. RM. 1982:403-428.

2. French AD: Physical and theoretical methods for determining the supramolecular structure of cellulose. In In Cellulose chemistry and its applications. Volume 1985. New York: Halsted Press, John Wiley;Nevell TP, Zeronian, SH 84-111.

3. Wong HC, Fear AL, Calhoon RD, Eichinger GH, Mayer R, Amikam D, Benziman M, Gelfand DH, Meade JH, Emerick AW, Bruner R, Ben-Bassat A, Tal R: Genetic organization of the cellulose synthase operon in Acetobacter xylinum. In Proc Natl Acad Sci. Volume 87. USA; 1990:8130-8134.

4. Kawano S, Tajima K, Uemori Y, Yamashita H, Erata T, Munekata M, Takai M: Cloning of cellulose synthesis related genes from Acetobacter xylinum ATCC23769 and ATCC53582: comparison of cellulose synthetic ability between strains. DNA Res 2002, 9:149-156.

doi:10.1186/1753-6561-8-S4-P176

Cite this article as: de Melo et al: Cloning of upstream region and cellulose synthase operon genes involved in bacterial cellulose biosynthesis by Gluconacetobacter hansenii ATCC23769. BMC Proceedings 2014 8(Suppl 4):P176.

\section{Submit your next manuscript to BioMed Central} and take full advantage of:

- Convenient online submission

- Thorough peer review

- No space constraints or color figure charges

- Immediate publication on acceptance

- Inclusion in PubMed, CAS, Scopus and Google Scholar

- Research which is freely available for redistribution

Submit your manuscript at www.biomedcentral.com/submit
C Biomed Central 